\title{
A redescription of Ancylotrypa elongata Purcell, 1908, with first description of the male (Aranei: Cyrtaucheniidae)
}

\author{
Переописание Ancylotrypa elongata Purcell, 1908, и первое \\ описание самџа этого вида (Aranei: Cyrtaucheniidae)
}

\author{
Sergei L. Zonstein ${ }^{1}$, Yuri M. Marusik ${ }^{2,3}$, Seppo Koponen ${ }^{4}$ \\ С.А. Зонштейн ${ }^{1}$ Ю.М. Марусик ${ }^{2,3}$, С. Копонен ${ }^{4}$
}

\footnotetext{
${ }^{1}$ (corresponding author) Steinhardt Museum of Natural History, Tel-Aviv University, 69978 Tel-Aviv, Israel. Email: znn@post.tau.ac.il

${ }^{2}$ Institute for the Biological Problems of the North RAS, Portovaya Str. 18, Magadan 685000 Russia. Email: yurmar@mail.ru

2 Институт биологических проблем Севера ДВО РАН, Портовая 18, Магадан 685000 Россия.

${ }^{3}$ Department of Zoology \& Entomology, University of the Free State, Bloemfontein 9300, South Africa

${ }^{4}$ Zoological Museum, Biodiversity Unit, FI-20014, University of Turku, Finland. Email: sepkopo@utu.fi
}

KEY WORDS: Spiders, Araneae, Mygalomorphae, Africa, Botswana, Kalahari.

КЛЮЧЕВЫЕ СЛОВА: Пауки, Araneae, Mygalomorphae, Африка, Ботсвана, Калахари.

ABSTRACT. Ancylotrypa elongata Purcell, 1908 is redescribed on the base of the holotype and specimens collected from Botswana; the male of this species is described for the first time.

How to cite this article: Zonstein S.L., Marusik Yu.M., Koponen S. 2018. A redescription of Ancylotrypa elongata Purcell, 1908, with first description of the male (Aranei: Cyrtaucheniidae) // Arthropoda Selecta. Vol.27. No.3. P.227-231. doi: 10.15298/arthsel. 27.3.05

РЕЗЮМЕ. Ancylotrypa elongata Purcell, 1908 переописывается по голотипу и собранным в Ботсване экземплярам; впервые описывается самец этого вида.

\section{Introduction}

The spider genus Ancylotrypa Simon, 1889 currently comprises 44 species widely distributed in Africa from Cameroon and Ethiopia in the north to the southernmost tip of the continent [WSC, 2018]. Most of these species remain to be known only from the original descriptions made at the end of the 19th beginning of the 20th century. Only a third (14) of the species are known from both sexes, while 9 species are known only from males, 21 only from females (including $A$. coloniae Pocock, 1902 with an unspecified sex of the only collected specimens; some characters in the original description allow to consider that Pocock [1902] designated a female as the holotype). Raven [1985] re-studied the type species of Ancylotrypa, $A$. fossor Simon, 1889, delimited and rediagnosed this genus, as well as other mygalomorph genera; he also transferred this genus from Ctenizidae to Cyrtaucheniidae and considered it a senior synonym of Pelmato- rycter Pocock, 1902. Information on some species of Ancylotrypa was reported on in several publications [Dippenaar-Schoeman, Jocqué, 1997; Dippenaar-Schoeman, 2002, 2014; Jocqué, Dippenaar-Schoeman, 2006]. Nevertheless, this genus has never been revised in its entirety. The structure of the spermathecae was depicted only for the type species [Raven, 1985, fig. 201].

One of the poorly known congeners, Ancylotrypa elongata, was described by Purcell [1908] from Kooa $\left(24^{\circ} 51^{\prime} \mathrm{S}, 24^{\circ} 28^{\prime} \mathrm{E}\right)$ in Bechuanaland, which corresponds to the recent Sevrelela in the Southern District of Botswana. The species remained known only from a single female, until several decades later it was also recorded from the neighbouring Omaheke Region of Namibia [Griffin, Dippenaar-Schoeman, 1991: Central Kalahari Region]. Nevertheless, males of $A$. elongata were not described and their characters remained unknown until now.

The present study, intending to fill this gap, is based on the occurrence of a few specimens belonging to Ancylotrypa in the collection of the Zoological Museum, University of Turku, Finland. After examination, these spiders were assigned to A. elongata; the diagnosis and a redescription of this species (including a first description of the male) are provided below.

\section{Material and methods}

The study is based on the re-examination of the holotype and the investigation of some additional material from Botswana. Specimens from the following spider collections were studied: MNB - Museum für Naturkunde, Berlin, Germany; ZMUT - Zoological Museum, University of Turku, Finland.

Photographs were taken using a Zeiss Discovery V20 stereomicroscope with a Canon PowerShot G9 
camera, and prepared using the Helicon Focus 6.3.2 Pro (http://www.heliconsoft.com). Palp and legs measurements are given as follows: total (femur, patella, tibia, metatarsus, tarsus). All measurements are given in millimetres.

Abbreviations: ALE — anterior lateral eyes, AME anterior median eyes, d - dorsal, $\mathrm{p}$ - prolateral, pd prodorsal, PLE - posterior lateral eyes, PLS - posterior lateral spinnerets, PME — posterior median eyes, PMS - posterior median spinnerets, PTC - paired tarsal claws, $\mathrm{pv}$ - proventral, $\mathrm{r}$ - retrolateral, $\mathrm{rd}$ retrodorsal, rv - retroventral, v — ventral, WSC World Spider Catalog.

\section{Taxonomic survey}

\section{Ancylotrypa elongata Purcell, 1908} Figs 1-16.

A. elongata Purcell 1908: 211 (†).

A. elongata: Eagle, 1985: 132.

A. elongata: Griffin, Dippenaar-Schoeman, 1991: 156.

A. elongata: Dippenaar-Schoeman, 2002: 46.

A. elongata: Dippenaar-Schoeman, van den Berg, 2010: 54.

MATERIAL EXAMINED: BOTSWANA: holotype + , Kalahari Desert, Southern District, Kooa (=Sevrelela), 1904, L. Schultze (MNB 884); $2 \sigma^{7} \sigma^{7}, 2$ 우, Kalahari Desert, Kgalagadi District, Lotlhake Pan eastern of Tshane, 19-28.07.1973, R. Hakanen (ZMUT).

DIAGNOSIS. Females of Ancylotrypa elongata resemble those of $A$. schultzei (Purcell, 1908) in habitus, but differ from them in having even paler colouration (in the former and the latter species the ground colour is pale yellowish and pale yellowish brown, respectively; Fig. 10, cf. Dippenaar-Schoeman, 2014: 389, text figure). The truncated apical segment of the PLS seems considerably shorter in $A$. elongata than in any other species of Ancylotrypa. Males of A. elongata can be distinguished from most other Ancylotrypa males, due to their short palpal tibia and embolus which look (together or one of them) shorter than in males of other species (Figs 6-8; cf. Hewitt, 1916: 194, pl. 6, figs 15; 1919, fig. 9; Lawrence, 1937, fig. 1b; Lessert, 1938, fig. 5; Caporiacco, 1949, fig. 1; Roewer, 1953, fig. 14A; Dippenaar-Schoeman, 2002, fig. 25h).

MALE. Body length 6.70. Habitus as shown in Fig. 1.

Color in alcohol: carapace, chelicerae, sternum, labium, palps and proximal leg segments from coxae to tibiae almost uniformly pale yellowish white; metatarsi, tarsi and spinnerets slightly darker (yellowish white); eye tubercle brownish black; abdomen very pale milky white; slightly darker dorsal abdominal pattern represented by short and narrow interrupted median stripe consisting of few diffuse brownish spots.

Prosoma as in Figs 2 and 4. Carapace 2.66 long, 2.02 wide. Eye tubercle as shown in Fig. 3. Eye diameters and interdistances: AME 0.12(0.17), ALE 0.16, PLE 0.13, PME 0.09, AME-AME 0.09(0.04), ALEAME 0.03(0.01), ALE-PLE 0.05, PLE-PME 0.01, PME-PME 0.24. Thoracic fovea approximately equal in width to PME-PME, weakly procurved. Chelicerae: each furrow with 6 promarginal teeth and approximately 15 densely clustered thornlike mesobasal denticles; rastellum consists of two heavy cone teeth on low mound and about 20 smaller cone teeth in front of fang base. Bases of chelicera visible through translucent integument and appears eye-brows like $(E b)$. Labium 0.48 long, 0.83 wide, without cuspules. Sternum 2.40 long, 1.89 wide. Posterior pair of sternal sigilla small elongate, located distantly from sternal margin and inconspicuous. No cuspules on maxillae. Serrula not evident (under light microscope at magnification 150x).

Palp and legs measurements: palp -2.16 (1.23, $0.60,0.85,-, 0.48)$; I $-8.34(2.42,1.15,1.93,1.68$, $1.16)$; II - $7.15(2.06,1.02,1.53,1.39,1.15)$; III 5.85 (1.67, $0.71,0.87,1.41,1.19)$ : IV -9.28 (2.20, $1.19,2.59,1.89,1.41)$.

Palp and leg structures. Tibia and metatarsus I as shown on Fig. 5. Megaspines undeveloped. Spines (palp, patella IV, tarsi I-IV entirely, and femur I dorsally, aspinose). Leg I: femur pd0-1a; patella p2-3, v0-1; tibia p2, r2; v6-7, metatarsus v1a. Leg II: femur d01b, pd0-1a; patella p2; tibia p2, v5-6; metatarsus v3. Leg III: femur d0-1b, pd1-2a; patella p20-25, r3; tibia d3, p6, r2a, v3a; metatarsus p2, rd4, v2a. Leg IV: femur d3-4; tibia r1, v2-6; metatarsus r2, v10. Metatarsal preening combs absent. Scopula: rudimentary, fine, sparse, located subapically and widely divided on tarsi I and II; elsewhere absent. Trichobothria: 2 rows of 7-12 in each row on tibiae, 7-17 on metatarsi, 6-12 on tarsi, 5 on cymbium. PTC I-II, and III with 8-10, and 5-6 teeth in each row, respectively. PTC IV long and narrow, slightly curved and bare, without teeth. Unpaired tarsal claw small and sharply curved.

Palp. Palp with relatively short (2.5 time longer than wide) and noticeably swollen tibia in the proximal half and relatively long cymbium (Fig 6, more than $1 / 2$ of tibia length)). Bulb pyriform, 1.5 times longer than wide with gradually tapering, moderately short (as long as tegular part of the bulb) and sideward directed embolus (Figs 7-8).

Spinnerets (Fig. 9). PMS: length 0.27; diameter 0.14. PLS: maximal diameter 0.33 ; length of basal, medial and apical segments $0.41,0.26,0.19$, respectively; total length 0.86; apical segment domed.

FEMALE. Body length 15.50. Habitus as shown in Fig. 10. Colour as in male, but carapace with large light brown spot around thoracic fovea; dorsal abdominal pattern better developed, with broken («dotted»), more contrast medium brown median strip.

Prosoma as in Figs 11 and 13. Carapace 5.21 long, 3.22 wide. Eye tubercle as shown in Fig. 12. Eye diameters and interdistances: AME 0.14(0.20), ALE 0.29, PLE 0.15, PME 0.12, AME-AME 0.16(0.10), ALEAME 0.08(0.05), ALE-PLE 0.07, PLE-PME 0.06, PME-PME 0.44. Thoracic fovea as in male. Chelicerae: each furrow with 8-9 promarginal teeth and 12-13 densely clustered thornlike mesobasal denticles; rastellum consists of 3-4 heavy cone teeth on low mound and about 30 smaller cone teeth in front of fang base. 

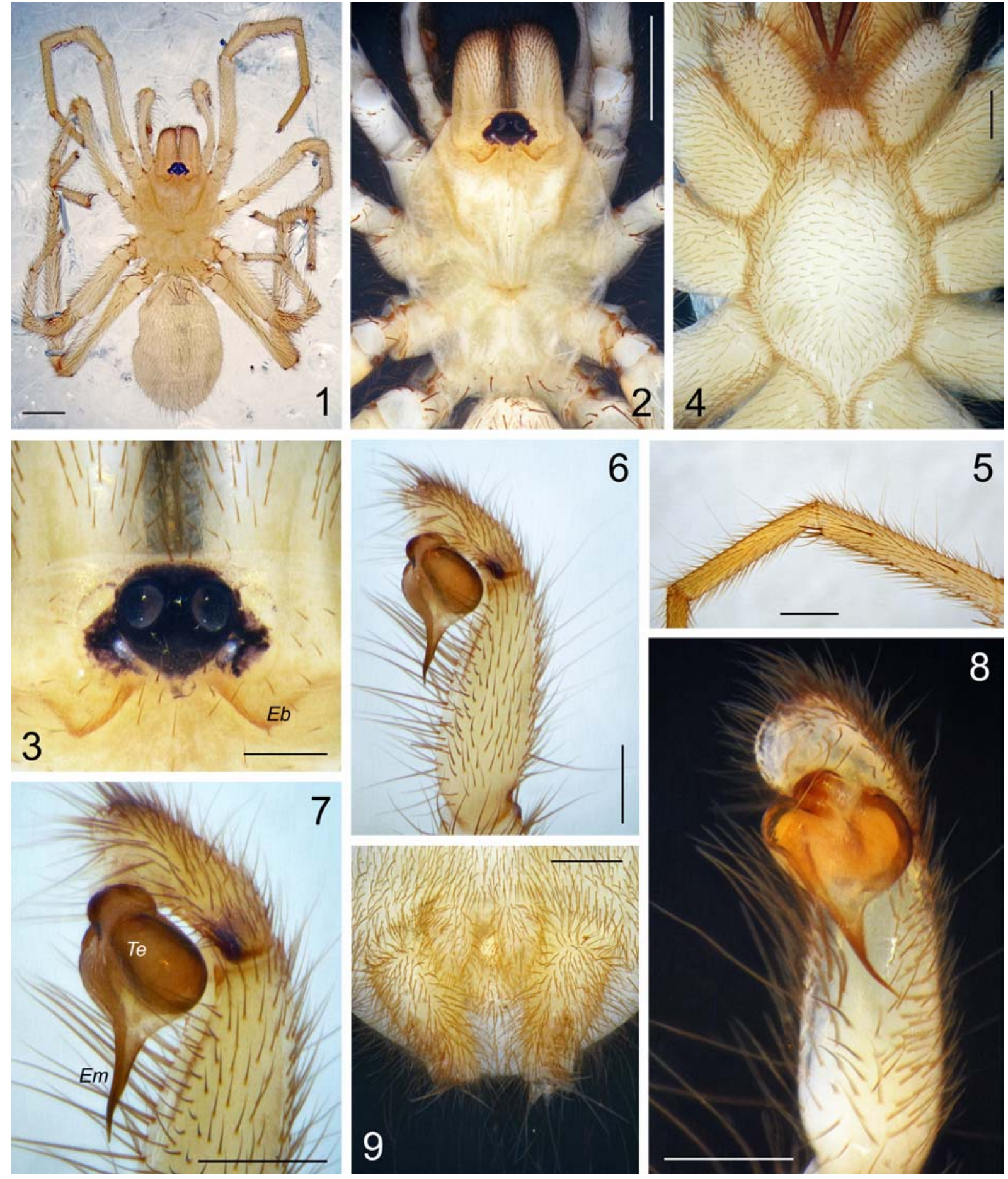

Figs. 1-9. Ancylotrypa elongata Purcell, 1908, male (ZMUT): 1 - habitus, dorsal view; 2 - prosoma, dorsal; 3 - clypeus and eye tubercle, dorsal; 4 - prosoma, ventral; 5 - tibia and metatarsus I, prolateral; $6-$ distal palpal segments showing bulb and embolus, retrolateral; 7 - bulb and embolus close up, retrolateral; 8 - same, ventral; 9 - spinnerets, ventral. Scale bars for Figs 1,2 - 1.0 mm, for Figs 3, 6-9-0.25 mm, for Figs 4, $5-0.5 \mathrm{~mm}$. Abbreviations: $E b-$ "eye-brow", $E m-$ embolus, $T e-$ tegulum.

Рис. 1-9. Ancylotrypa elongata Purcell, 1908, самец (ZMUT): 1 - общий вид сверху; 2 - просома сверху; 3 - наличник и глазной бугорок сверху; 4 - просома снизу; 5 - голень и предлапка I сбоку (снутри); 6 - дистальные сегменты педипальпы, бульбус и эмболюс сбоку (снаружи); 7 - бульбус и эмболюс при большем увеличении сбоку (снаружи); 8 - то же, снизу; 9 паутинные бородавки снизу. Масштаб для рис. $1,2-1,0$ мм, для 3, 6-9 - 0,25 мм, для 4, $5-0,5$ мм. Сокращения: $E b-$ “брови”, $E m$ - эмболюс, $T e$ - тегулум. 

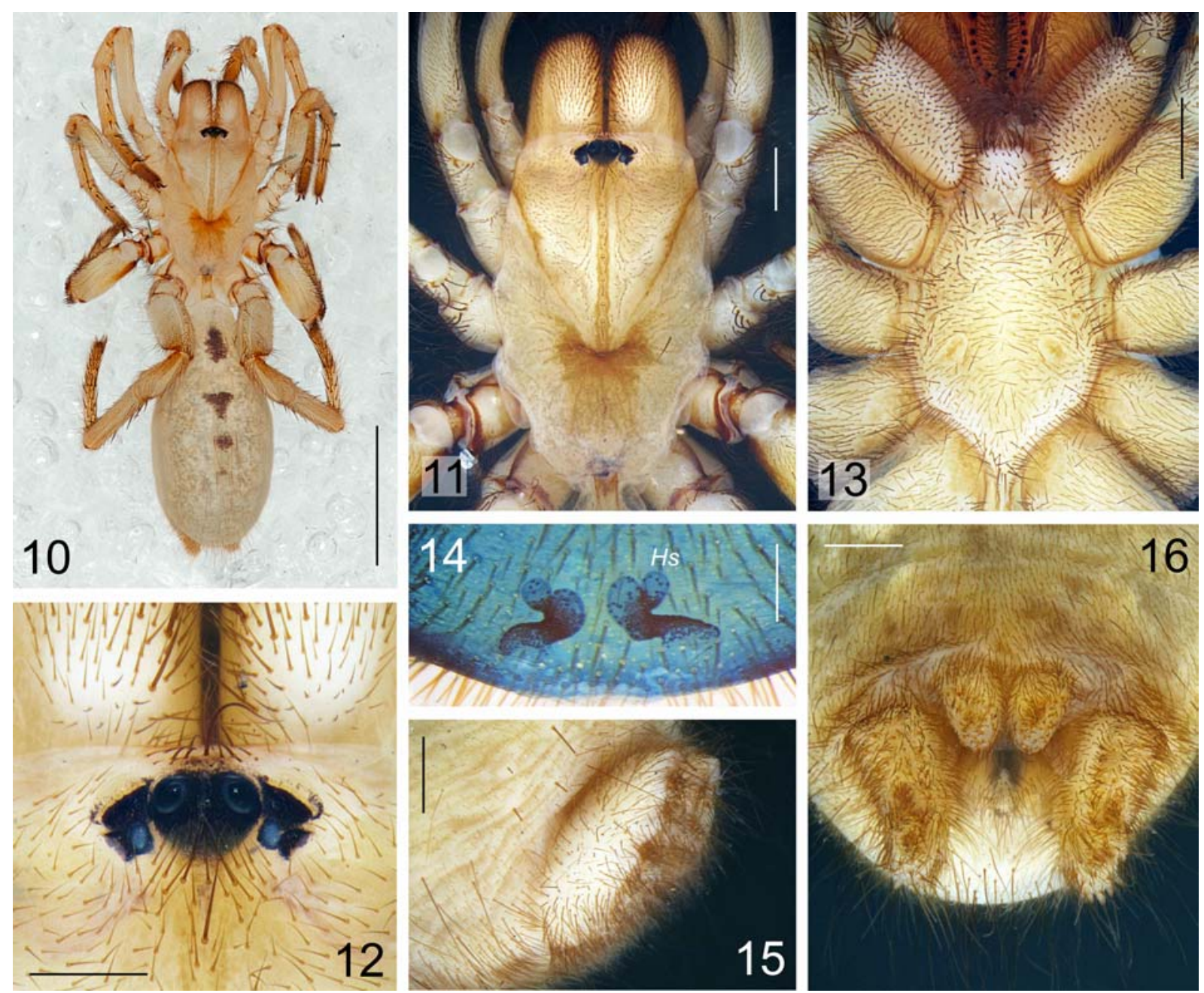

Figs. 10-16. Ancylotrypa elongata Purcell, 1908, female (ZMUT): 10 - habitus, dorsal view; 11 - prosoma, dorsal; 12 - clypeus and eye tubercle, dorsal; 13 - prosoma, ventral; 14 - spermathecae, dorsal; 15, 16 - spinnerets, lateral and ventral, respectively. Scale bars for Fig. $10-5.0 \mathrm{~mm}$, For Figs 11, $13-1.0 \mathrm{~mm}$, for Figs 12, 15, $16-0.5 \mathrm{~mm}$, for Fig. $14-0.25 \mathrm{~mm}$. Abbreviation: $H s-$ head of spermatheca.

Рис. 10-16. Ancylotrypa elongata Purcell

, 1908, самка (ZMUT): 10 - общий вид сверху; 11 - просома сверху; 12 - наличник и глазной бугорок сверху; $13-$ просома снизу; 14 - сперматеки сверху (изнутри); 15, 16 - паутинные бородавки соответственно сбоку и снизу. Масштаб для рис. $10-5,0$ мм, для $11,13-1,0$ мм, для $12,15,16-0,5$ мм, для $14-0,25$ мм. Сокращение: $H s-$ головка сперматеки.

Labium 0.64 long, 0.72 wide, without cuspules. Sternum 2.89 long, 2.19 wide; sternal sigilla as in male. No cuspules on maxillae. Serrula not evident (under light microscope at magnification 150x).

Palp and legs measurements: palp - 6.40 (2.27, $1.19,1.52,-, 1.42) ; \mathrm{I}-10.67(3.22,2.13,2.26,1.86$, $1.20)$; II - $9.07(2.89,1.74,1.82,1.45,1.17)$; III $6.92(2.13,1.13,0.80,1.57,1.29):$ IV -13.24 (3.43, $2.14,3.98,2.36,1.33)$.

Palp and leg structures. Spines (patella I aspinose). Palp: femur d3, pd1a; patella p1; tibia p5 bristles; tarsus v6-9. Leg I: femur d4-5; tibia v6, metatarsus 10-11; tarsus v5. Leg II: femur d4-5; patella p1-2; tibia p3, v6; metatarsus pd3, v6; tarsus v2. Leg III: femur pd15-20; patella p20-25, r20 long thick bristles; tibia d2-3, p8, r3-4, v6-7; metatarsus p8-9, rd9-
11, r1-2; v8-9; tarsus p4, v4. Leg IV: femur d4-6; patella v1; tibia rd4, v10-12; metatarsus p2, rd3; r2a; v20-22; tarsus $v \sim 20$. Tibia IV retrolaterally smooth and bald, without hairs. Metatarsal preening combs absent. Scopula: moderately fine and dense, widely divided on palpal tarsus, metatarsus I and tarsus I; prolateral and distal on metatarsus II; prolateral on tarsus II; elsewhere absent. Trichobothria: 2 rows of $8-$ 11 in each row on tibiae, 10-12 on metatarsi, 9-10 on tarsi I-IV, 5-6 on palpal tarsus. PTC I-II with 10-12, teeth in each row. PTC III with 7-8 teeth in outer row and 3 teeth in inner row. PTC IV with 3 teeth only in inner row. Unpaired tarsal claw small and sharply curved. Palpal claw with 4 prolateral teeth.

Vulva as in Fig. 14, with pair of converging spermathecae, bearing globular heads located laterally; bases 
of spermathecae separated by about 1.5 of diameter; anterior part of spermathecae separated by less than diameter; heads about 2 times thinner than terminal part of spermathecae; spermathecae with dense pore gland in basal and mesal parts, and sparse in the heads $(H s)$ and terminal parts of spermathecae.

Spinnerets (Figs 15-16). PMS: length 0.69; diameter 0.44. PLS: maximal diameter 0.76; length of basal, medial and apical segments $0.92,0.31,0.23$, respectively; total length 1.46; apical segment domed.

VARIATION. Length of the carapace varies in males from 2.66 to 3.08 , in females - from 4.59 to 5.21. The colouration in alcohol in males does not show any noticeable difference between them, while the second female has more intense and contrasting brown spots on the carapace and dorsal abdomen.

DISTRIBUTION. Southern Botswana and eastern Namibia.

\section{Acknowledgements}

We thank Jason Dunlop (MNB) for the possibility to examine the holotype of Ancylotrypa elongata. We are grateful to Ansie Dippenaar-Schoeman (Agricultural Research Council, Pretoria, South Africa), Rudy Jocqué (Musée Royal de l'Afrique Centrale, Tervuren, Belgium), Astri Leroy (Ruimsig, South Africa) and an anonymous reviewer for their valuable comments and recommendations and for linguistic and stylistic corrections which helped to improve the original manuscript. This study was partially supported by the Ministry of Absorption, Israel.

\section{References}

Caporiacco L. 1949. Aracnidi della colonia del Kenya raccolti da Toschi e Meneghetti negli anni 1944-1946 // Commentationes Pontificia Academia Scientiarum. Vol.13. P.309-492.
Dippenaar-Schoeman A.S. 2002. Baboon and trapdoor spiders of southern Africa: an identification manual // Plant Protection Research Institute Handbook. Agriculture Research Council Publications. Vol.13. 128 p.

Dippenaar-Schoeman A.S. 2014. Field guide to spiders of South Africa. Pretoria: LAPA Publishers Ltd. 432 p.

Dippenaar-Schoeman A.S., Jocqué R. 1997. African Spiders: An Identification Manual // Plant Protection Research Institute Handbook. Agriculture Research Council Publications. Vol.9. $392 \mathrm{p}$.

Dippenaar-Schoeman A.S, Van den Berg A.M. 2010. Spiders of the Kalahari // Plant Protection Research Institute Handbook. Agriculture Research Council Publications. Vol.18. 120 p.

Eagle V. 1985. A survey of the spider fauna of Botswana (Project report June 1984) // Botswana Notes and Records. Vol.17. P.131-139.

Griffin E., Dippenaar-Schoeman A.S. 1991. A checklist of, and reference to, the Namibian spider fauna Arachnida, Araneae) // Cimbebasia. Vol.13. P.155-181.

Hewitt J. 1916. Descriptions of new South African spiders // Annals of the Transvaal Museum. Vol.5. P.180-213.

Hewitt J. 1919. Descriptions of new South African Araneae and Solifugae // Annals of the Transvaal Museum. Vol.6. P.63111.

Jocqué R., Dippenaar-Schoeman A.S. 2006. Spider families of the World. Musée Royal de 1'Afrique Centrale, Tervuren. 336 p.

Lawrence R.F. 1937. A collection of Arachnida from Zululand // Annals of the Natal Museum. Vol.8. P.211-273.

Lessert R. 1938. Araignées du Congo belge (Première partie) // Revue de Zoologie et de Botanique Africaines. T.30. P.424457.

Pocock R.I. 1902. Descriptions of some new species of African Solifugae and Araneae // Annals and Magazine of Natural History. Ser.7. Vol.10. P.6-27.

Purcell W.F. 1908. Araneae// Schultze L. (Hrsg.). Forschungsreise in Südafrika, 1(2). Denkschriften der Medizinisch-Naturwissenschaftlichen Gesellschaft zu Jena. Bd.13. S.203-246.

Raven R.J. 1985. The spider infraorder Mygalomorphae (Araneae): cladistics and systematics // Bulletin of the American Museum of Natural History. Vol.182. P.1-180.

Roewer C.F. 1953. Araneae-Orthognatha (Arachnoidae) // Exploration du Parc National de 1'Upemba, Mission G. F. de Witte. Vol.22. P.1-80.

World Spider Catalog. 2018. World Spider Catalog. Available from: http://wsc.nmbe.ch, version 19.0 (accessed 8.05.2018).

Responsible editor K.G. Mikhailov 